\title{
MENYOAL PEMULIHAN BAGI ANAK KORBAN KEKERASAN DI INDONESIA
}

\author{
Nur Hasyim \\ Universitas Islam Negeri Walisongo Semarang \\ nurhasyim@walisongo.ac.id
}

\section{ABSTRAK}

Kekerasan terhadap anak menjadi salah satu masalah serius yang dihadapi Indonesia saat ini yang menuntut langkah-langkah terstruktur untuk mencegahnya. Pemerintah telah melakukan langkah-langkah legislasi serta membangun mekanisme pemulihan dengan membangun lembaga-lambaga penyedia layanan untuk anak korban kekerasan, namun masih mengalami hambatan. Artikel ini bertujuan mengidentifikasi tantangan-tantangansekaligusmenawarkan rekomendasi yang harus dilakukan oleh berbagai pihak terkait pemulihan untuk anak korban kekerasan di Indonesia. Tantangan yang dihadapi dalam pemulihan anak korban kekerasan di Indonesia antara lain: Pertama, pemahaman aparat hukum tentang substansi undang-undang terkait dengan kekerasan terhadap perempuan dan anak. Kedua, layanan pemulihan sebagai hak kadangkala harus dikalahkan dengan persoalan administrasi. Ketiga, perempuan atau korban kekerasan harus mengeluarkan biaya untuk mendapatkan layanan kesehatan seperti pemeriksaan kesehatan atau untuk mendapatkan visum. Keempat, adanya upaya penyelesaian di luar pengadilan. Kelima, terbatasnya anggaran untuk penanganan kasus kekerasan terhadap perempuan.

Kata kunci : kekerasan terhadap anak, hak anak, hak asasi manusia, pemulihan 


\section{ABSTRAK}

Violence against children is one of the most serious problems facing Indonesia that should be addressed through measurable and structured strategies and efforts. The government has taken legislative steps and established a recovery mechanism by establishing a service provider institution for child victims of violence, even some obstacles still facing this effort. This article aims to identify challenges while offering recommendations to be made by stake holders on recovery for child victims of violence in Indonesia. Based on the data analyzed in this study, the challenges faced in recovery process of child victims of violence in Indonesia are: Firstly, the understanding of legal apparatus on the substance of violence against women and children's law; Secondly, recovery services as a right sometimes must be defeated by administrative matters. Thirdly, women or victims of violence must pay for health services such as medical examinations or visa obtaining. Fourthly, there is an out-of-court adjudication. Fifth, the limited budget for handling cases of violence against women. Thus, massive efforts to resolve these problems become a prerequisite for the realization of sustainable recovery of child victims of violence.

Keywords: violence against children, children rights, human rights, recovery

\section{A. Pendahuluan}

Kasus YY di Bengkulu beberapa waktu lalu mengundang keprihatinan mendalam akan persoalan kekerasan terhadap perempuan dan anak di Indonesia. Kasus tersebut sekali lagi menjadi kasus yang membuka mata banyak pihak akan situasi anak, lebih khusus, anak perempuan di Indonesia akan kerentanan mereka terhadap kekerasan, mulai dari kekerasan psikis sampai kekerasan fisik dan seksual. Lebih lanjut, kasus YY juga mengingatkan bahwa kekerasan terhadap anak dapat menyertakan akibat yang paling fatal yakni kematian. Kasus YY juga menggambarkan, meskipun semua anak tanpa membedakan jenis kelamin memiliki kerentanan, anak 
perempuan menjadi kelompok yang paling rentan di banding dengan kelompok lainnya. Dan yang tak kalah memprihatinkan adalah ketika kita menemukan fakta bahwa di antara pelaku kekerasan seksual terhadap YY adalah juga berstatus anak.

Kerentanan anak Indonesia terhadap kekerasan cukup gamblang, tidak hanya dari pemberitaan tentang tindak kekerasan terhadap mereka yang seolah tanpa jeda, data-data statistik dari beberapa lembaga yang terkait dengan pemenuhan dan perlindungan hak anak di Indonesia cukup menguatkan sinyalemen kerentanan anak di Indonesia. Seperti dilaporkan oleh Komisi Nasional Perlindungan Anak Indonesia (KPAI) yang mencatat bahwa angka kekerasan terhadap anak pada tahun 2014 mencapai 5.066 dan kecenderungannya meningkat dari tahun ke tahun (Setyawan, 2015). Data serupa juga tergambar dalam press release Kementerian Pemberdayaan Perempuan dan Perlindungan Anak yang mencatat bahwa jumlah kasus kekerasan terhadap perempuan pada tahun 2012 mencapai 18.718 kasus dengan jumlah korban yang berstatus anak mencapai 35 persen (Kementerian Perbedayaan Perempuan dan Perlindungan Anak, 2016). Data kedua lembaga lembaga negara tersebut diperkuat dengan data Komisi Nasional Anti Kekerasan terhadap Perempuan (Komnas Perempuan) yang menyebutkan dalam catatan tahunannya bahwa berdasarkan data kasus kekerasan pada ranah personal pada tahun 2015, jumlah korban yang berstatus anak mencapai 930 kasus atau mencapai 8 persen dari total kasus kekerasan terhadap perempuan yang mencapai 11.207. (Komnas Perempuan, 2016 : 17-18)

Persoalan kekerasan terhadap anak ini menambah daftar panjang persoalan yang dihadapi oleh anak Indonesia yang sejatinya sudah cukup banyak. Di antara persoalan yang dihadapi oleh anak di Indonesia adalah; pertama, angka kematian bayi, menurut Survei Demografi dan Kesehatan Indonesia (SDKI) tahun 2012 bahwa angka kematian bayi mencapai 32 per 1000 kelahiran hidup, artinya setiap satu dari 31 anak yang lahir di Indonesia meninggal sebelum mencapai 
umur 1 tahun (BKKBN, BPS, Kementerian Kesehatan,, 2013: 110). Kedua, gizi buruk dan stunting, sebagaimana di disebutkan dalam Riset Kesehatan Dasar tahun 2013 menunjukkan bahwa prevalensi stunting (anak dengan postur tubuh tidak maksimal) mencapai 37,2 persen atau sekitar 8 juta anak Indonesia (Kementerian Kesehatan RI, 2014). Ketiga, narkoba dan anak-anak yang hidup dalam lingkungan buruk seperti pekerja anak dan anak-anak yang berhadapan dengan hukum. Menurut data Komnas Perlindungan Anak bahwa jumlah anak yang berhadapan dengan hukum dari tahun 2011 sampai April 2015 mencapai 6006 (Setyawan, 2015).

Persoalan-persoalan yang dihadapi anak di Indonesia ini jelas akan mempengaruhi masa depan Indonesia sebagai bangsa mengingat anak-anak mengisi sepertiga dari komposisi populasi Indonesia atau sekitar 82,85 juta (Kementerian Pemberdayaan Perempuan dan Perlindungan Anak Bekerjasama dengan Biro Pusat Statistik, 2015 : 2) dan mereka akan akan menjadi penerus generasi sekarang untuk membawa Indonesia bersaing dengan bangsa-bangsa lain dalam pergaulan global bangsa-bangsa di dunia. Mana mungkin mereka memiliki daya saing yang kuat dengan anak-anak di negara lain ketika di masa kanak-kanak, mereka harus berjibaku dengan banyak persoalan yang dapat menghalangi mereka untuk mengembangkan potensi maksimalnya sebagai manusia.

Tidak hanya persoalan memastikan masa depan bangsa ini yang gemilang, melindungi anak Indonesia dari kekerasan dan melindungi mereka dari persoalan-persoalan sosial lainnya adalah kewajiban negara sebagai lembaga yang memiliki mandat (duty bearer) menghargai, melindungi, dan memenuhi hak-hak asasi manusia. Lebih-lebih, Indonesia telah mengikatkan diri pada beberapa konvensi dan kesepakatan internasional terkait dengan hak asasi manusia termasuk Konvensi Hak Anak (Child Rights Convention). Selain itu, konsititusi Indonesia (UUD 1945) telah mengamanatkan bahwa negara memiliki kewajiban untuk menjamin hak-hak anak sebagai warga negara sebagaimana tertuang dalam 
BAB XA tentang Hak Asasi Manusia. Hal ini diperkuat dengan aturan-aturan perundangan di bawahnya seperti Undang-Undang Perlindungan Anak dan peraturan perundangan lainnya.

Paper ini memberikan perhatian khusus terhadap persoalan pemulihan bagi anak korban kekerasan di Indonesia sebagai ikhtiar untuk memotret dinamika penanganan anak korban kekerasan di Indonesia. Paper ini memaparkan pembacaan penulis sebagai aktivis yang bekerja di Women's Crisis Center atau Pusat Krisis untuk Perempuan Rifka Annisa Yogyakarta dan pernah bekerja bersama dengan Forum Pengada Layanan, sebuah jaringan nasional yang beranggotakan 33 organisasi perempuan yang bekerja untuk perempuan dan anak korban kekerasan selama tahun 2015 sekaligus sebagai akademisi yang memiliki minat pada isu gender dan kekerasan berbasis gender.

Paper ini juga mengidentifikasi tantangan pemulihan bagi anak korban kekerasan dan tawaran rekomendasi yang perlu dilakukan oleh berbagai pihak di Indonesia dalam upaya memperkuat pemulihan anak korban kekerasan sebagai bagian dari keseluruhan upaya pemenuhan hak anak sebagaimana diamanatkan oleh konstitusi, peraturan perundangan maupun perjanjian internasional tentang hak asasi manusia khususnya hak anak yang telah menjadi komitmen indonesia sebagai anggota Perserikatan Bangsa-Bangsa.

Data-data yang digunakan lebih beasal dari pengalaman lapangan dan sekaligus data kepustakaan, maka dalam analisisnya menggabungkan telaah isi (content analysis) dana telaah fenomenologis yang diharapkan mampu mengungkap dimensi noumena dibalik fenomena. Telaah isi diharapkan mampu menemukan makna terdalam dari suatu narasi data yang ditafsirkan dengan pendekatan hermeneutik. Dengan metode gabungan seperti itu diharapkan mampu menangkap substansi problematika penanganan pemulihan anak korban kekerasan di Indonesia. 


\section{B. Pembahasan}

\section{a. Mendefinisikan Pemulihan}

Di antara sedikit lembaga negara yang bekerja untuk hak asasi manusia yang memberikan perhatian terhadap konsep pemulihan untuk korban kekerasan, khususnya perempuan (termasuk anak perempuan) korban kekerasan adalah Komnas Perempuan. Selain merumuskan konsep pemulihan, di penghujung tahun 2015 lembaga HAM perempuan ini bersama Forum Pengada Layanan (FPL) untuk perempuan korban kekerasan di Indonesia menyelenggarakan konferensi tentang pemulihan pertama di Indonesia. Konferensi yang diselenggarakan di Kampus Universitas Sumatera Utara Medan ini mengupas situasi pemulihan perempuan korban kekerasan di Indonesia serta mendiskusikan secara konseptual tentang pemulihan bagi perempuan korban kekerasan (Hasyim, 2015).

Pemulihan menurut Komnas Perempuan tidak hanya sebatas pada pemenuhan kebutuhan segera korban kekerasan seperti penanganan medis, pendampingan psikologis, hukum dan psikososial, akan tetapi pemulihan mencakup penciptaan kondisi yang memungkinkan perempuan dan anak korban kekerasan kembali berdaya secara utuh sehingga mereka dapat mengambil keputusan untuk dirinya sendiri serta dapat berperan serta secara penuh sebagai warga negara. Oleh sebab itu, pemulihan menurut Komnas Perempuan selain terkait dengan kebutuhan korban sebagaimana telah disebutkan, juga mencakup pemenuhan hak-hak dasar mereka sebagai warga negara seperti pendidikan, kesehatan, kependudukan dan hak politik. Dalam kerangka pemulihan dalam makna luas ini, reintegrasi, kompensasi serta pencegahan keberulangan kekerasan menjadi bagian integral dari pemulihan (Komnas Perempuan, n.d.).

Sementara dalam Peraturan Pemerintah Nomor 4 tahun 2016 tentang Penyelenggaraan Kerjasama Pemulihan untuk Korban Kekerasan Dalam Rumah Tangga dijelaskan bahwa pemulihan korban adalah segala upaya untuk penguatan korban kekerasan dalam rumah tangga agar lebih berdaya, baik secara fisik maupun 
psikis. Karenanya penyelenggaraan pemulihan menurut peraturan pemerintah ini adalah segala tindakan yang meliputi pelayanan dan pendampingan kepada korban kekerasan dalam rumah tangga. Dengan batasan ini terlihat jelas bahwa pemulihan terbatas pada pemulihan aspek fisik dan psikis korban dan tidak mencakup aspek sosial, ekonomi dan politik korban.

Pemulihan dalam paper ini dibatasi pada proses pemenuhan kebutuhan korban baik pada saat krisis maupun kebutuhan korban untuk kembali bersosialisasi dengan lingkungan. Artinya pemulihan dalam paper ini adalah proses-proses pemenuhan kebutuhan penanganan medis, pendampingan psikologis, pendampingan hukum, pendampingan psiko-sosial seperti pemulangan dan reintegrasi dengan keluarga dan masyarakat korban.

b. Pemulihan sebagai Hak Anak Korban Kekerasan

UUD 1945 Perubahan pasal 28G secara jelas menyebut bahwa setiap warga negara memiliki hak dasar untuk hidup, aman atau terbebas dari segala bentuk diskriminasi serta perlakuan yang merendahkan martabat kemanusiaan. Sebagai hak dasar warga negara maka hak-hak tersebut wajib dilindungi, dihormati dan diupayakan pemenuhannya oleh negara sesuai prinsip respect (hormati), protect (lindungi) and fulfill (penuhi) dalam kerangka hak asasi manusia. Anak-anak sebagai warga negara adalah bagian tak terkecuali untuk dipenuhi hak dasarnya lebih-lebih anak-anak merupakan kelompok paling rentan dalam struktur sosial karenanya negara wajib mengupayakan upaya ekstra (affirmasi) untuk perlindungan hak-hak mereka.

Hak anak bahkan tidak sebatas pada beberapa hak dasar sebagaimana disebutkan dalam konsititusi namun diperluas dalam konvensi hak anak yang sudah diratifikasi dan dikuatkan dalam Undang Undang Nomor 23 tahun 2002 tentang Perlindungan Anak. Sementara tentang hak anak meliputi; hak sipil dan kebebasan fundamental, hak kesehatan, gizi, air dan sanitasi lingkungan, hak lingkungan keluarga dan perawatan alternatif, hak pendidikan, waktu 
bersantai dan bermain serta kegiatan budaya, dan hak perlindungan khusus. Dengan kententuan konvensi dan undang-undang ini maka negara sebagai duty bearer dengan segala sumber daya yang dimiliki berkewajiban untuk merealisasikan secara bertahap (progressive realization) untuk pemenuhan hak-hak anak.

Lebih lanjut dalam Undang-Undang No. 23 tahun 2004 tentang Penghapusan Kekerasan dalam Rumah Tangga (PKDRT) disebut secara jelas hak-hak korban, sebagaimana tertuang di dalam pasal 10 yang menyebutkan bahwa korban kekerasan dalam rumah tangga memiliki hak mendapatkan perlindungan dari berbagai pihak terkait seperti kepolisian, kejaksaan, pengadilan, pekerja sosial. Korban juga berhak mendapatkan layanan kesehatan, pendampingan psikologis dan hukum serta pendampingan rohani.

Dalam kerangka hak asasi manusia ini maka pemulihan anak korban kekerasan adalah hak bukan semata kebutuhan. Sebagai hak maka pemerintah sebagai representasi negara memiliki kewajiban tidak hanya kewajiban untuk melakukan (obligation of conduct) yang meliputi menghormati, melindungi dan memenuhi akan tetapi juga kewajiban untuk memenuhi hasil (obligation of result) untuk pemajuan hak anak. Kewajiban untuk memenuhi hasil ini mengandaikan negara harus menggunakan sumber daya yang dimiliki untuk memastikan keberlanjutan dan peningkatan realisasi hak asasi manusia.

Pemenuhan kewajiban untuk melakukan maupun kewajiban untuk memenuhi hasil pemajuan hak pemulihan anak korban kekerasan oleh sebuah negara dinilai dari komitmen dan kemampuan negara atau pemerintah. Komitmen ini dapat berupa kebijakan seperti undang-undang, peraturan pemerintah dan perundangan lainnya yang mengatur tentang pemulihan untuk anak korban kekerasan. Sedangkan kemampuan pemerintah dinilai dari alokasi anggaran, ketersediaan staf yang kapabel, ketersediaan sarana dan fasilitas, barang dan jasa untuk pemulihan anak korban kekerasan.

Kewajiban negara dalam pemenuhan hak anak ini diatur 
dalam pasal 72 Undang-Undang Nomor 23 tahun 202 tentang Perlindungan Anak yang menyebutkan bahwa pemerintah

"bertanggung jawab atas pelaksanaan tahapan pada aspek legislatif, administratif, dan lainnya dengan memaksimalkan sumber daya yang ada, bertanggung jawab dalam hal pembuatan laporan kepada PBB dan masyarakat, dan bertanggung jawab untuk melakukan diseminasi Konvensi Hak Anak kepada semua pihak termasuk anak-anak"

\section{c. Kebijakan Terkait dengan Pemulihan Bagi Anak Korban Kekerasan di Indonesia}

Kebijakan tentang pemulihan untuk anak korban kekerasan dapat dilacak tidak hanya dari kebijakan-kebijakan tentang anak seperti Undang Undang Nomor 23 tahun 2002 tentang Perlindungan Anak beserta kebijakan turunannya akan tetapi juga dari perundangan lainnya yang terkait seperti Undang Undang Nomor 23 tahun 2004 tentang Penghapusan Kekerasan dalam Rumah tangga, Undangundang Nomor 13 tahun 2006 tentang Perlindungan Saksi Korban, Undang-Undang Nomor 21 tahun 2007 tentang Pemberantasan Tindak Pidana Perdagangan Orang dan peraturan lainnya yang terkait dengan penyelenggaraan pelayanan untuk korban kekerasan.

Dalam Undang-Undang Nomor 23 tahun 2002 tentang Perlindungan Anak, hal yang terkait dengan keharusan negara melindungi anak korban kekerasan tertuang dalam pasal 69 yang menyebutkan bahwa negara berkewajiban dan bertanggungjawab terhadap penyelenggaraan perlindungan bagi anak korban kekerasan melalui beberapa hal di antaranya (a) penyebarluasan dan sosialisasi ketentuan peraturan perundang-undangan yang melindungi anak korban tindak kekerasan; dan (b) pemantauan, pelaporan, dan pemberian sanksi.

Secara lebih jelas dan terperinci, Undang Undang Nomor 23 tahun 2004 tentang Penghapusan Kekerasan Dalam Rumah Tangga 
(UUPKDRT) sebagaimana tertuang dalam pasal 13 menyebutkan kewajiban yang harus ditunaikan negara terkait dengan pemulihan korban kekerasan meliputi penyediaan ruang khusus di kepolisian, menyediakan aparat, tenaga kesehatan, pekerja sosial dan pembimbing rohani serta membangun mekanisme kerjasama terpadu berbagai pihak yang terkait dengan korban kekerasan. Senada dengan UU Perlindungan Anak dan UUPKDRT, Undang-Undang Nomor 13 tahun 2006 tentang Perlindungan Saksi dan Korban juga mengatur pemulihan korban. Hal ini tertuang dalam pasal 6 yang menyebutkan bahwa korban pelanggaran hak asasi manusia berhak mendapatkan bantuan medis dan rehabilitasi psiko-sosial. Lebih lanjut, UU ini juga mengatur tentang kompensasi dan restitusi. Restitusi sebagaimana diatur dalam pasal 1 Undang-Undang Nomor 21 tahun 2007 tentang Pemberantasan Tindak Pidana Perdagangan Orang adalah pembayaran ganti kerugian yang dibebankan kepada pelaku berdasarkan putusan pengadilan yang berkekuatan hukum tetap atas kerugian material dana tau immaterial yang diderita korban atau ahli warisnya.

Jika beberapa undang-undang sebelumnya tidak mengatur tentang pemulangan dan reintegrasi, UU Penghapusan Tindak Pidana Perdagangan Orang mengatur secara jelas tentang pemulangan dan reintegrasi. Hal ini pada situasi tertentu relevan untuk anak korban kekerasan seksual yang harus tinggal di rumah aman karena alasan keamanan dan untuk kepentingan proses hukum dan pemulihan. Anak-anak korban kekerasan yang dipindahkan ke rumah aman ini juga membutuhkan proses pemulangan dan reintegrasi dengan komunitasnya. Pemulangan dan reintegrasi untuk korban tindak pidana juga diakomodir dalam Undang-Undang yaitu dalam pasal 52 UU Pemberantasan Tindak Pidana Perdagangan Orang yang mengatur kementerian atau lembaga dan tatacara penyelenggaraan pelayanan rehabilitasi kesehatan, rehabilitasi sosial, pemulangan, dan reintegrasi sosial.

Selain beberapa perundangan sebagaimana diuraikan, 
pemerintah telah mengeluarkan Peraturan Pemerintah Nomor 4 tahun 2006 tentang Penyelenggaraan Kerjasama Pemulihan Korban Kekerasan dalam Rumah Tangga. Peraturan ini mengatur dengan sangat rinci tentang keseluruhan penyelenggaraan pemulihan untuk perempuan korban kekerasan yang memiliki kaitan erat dengan penyelenggaraan pemulihan untuk anak korban kekerasan. Penyelenggaraan pemulihan menurut peraturan ini meliputi a. pelayanan kesehatan; b. pendampingan korban; c. konseling; d. bimbingan rohani; dan e. resosialisasi.

Pada tataran penyelenggaraan pemulihan untuk anak korban kekerasan, sebagaimana diamanatkan oleh beberapa undang-undang dan peraturan lainnya sebagaimana diuraikan, pemerintah telah mengembangkan pusat layanan terpadu untuk perempuan dan anak korban kekerasan atau yang lebih dikenal dengan P2TP2A (Pusat Pelayanan Terpadu Pemberdayaan Perempuan dan Anak). Lembaga ini telah tersebar di seluruh Indonesia baik di tingkat kabupaten/ kota atau propinsi bahkan pada wilayah-wilayah tertentu lembaga serupa dikembangkan sampai pada tingkat kecamatan dan desa. Data Kementerian Pemberdayaan Perempuan dan Perlindungan Anak tahun 2010 mencatat setidaknya ada 102 P2TP2A di tingkat Kabupaten/kota dan 19 di tingkat Propinsi (Murtakhamah, 2015).

Dalam rangka untuk memastikan perempuan dan anak korban kekerasan mendapatkan layanan pemulihan yang memadai sebagai bagian dari upaya pemenuhan hak perempuan dan anak, pemerintah melalui Kementerian Pemberdayaan Perempuan dan Perlindungan Anak menerbitkan Standar Pelayanan Minimal (SPM) untuk perempuan dan anak korban kekerasan sebagaimana tertuang dalam Peraturan Menteri Pemberdayaan Perempuan dan Perlindungan Anak Nomor 1 tahun 2010, namun SPM yang dinilai oleh banyak kalangan sangat komprehensif ini tidak dapat diberlakukan secara maksimal kepada lembaga penyedia layanan di tingkat daerah setelah lahirnya Undang-Undang Nomor 23 tahun 2014 tentang Pemerintah Daerah yang menyebutkan urusan perempuan dan anak 
sebagai urusan wajib yang menjadi kewenangan pemerintah daerah.

Sementara terkait dengan anggaran penyelenggaraan pemulihan untuk perempuan dan anak korban kekerasan dalam Peraturan Pemerintah Nomor 4 tahun 2006 telah disebutkan secara jelas bahwa pembiayaan untuk keseluruhan penyelenggaraan pemulihan untuk korban kekerasan dibebankan kepada Anggaran Pendapatan dan Belanja Negara (APBN) dan daerah (APBD) serta sumber-sumber lainnya yang tidak mengikat.

d. Tantangan Penyelenggaraan Mekanisme Pemulihan bagi Anak Korban Kekerasan di Indonesia

Sebagaimana telah didiskusikan bahwa pemerintah atas amanat undang-undang membangun lembaga penyedia layanan untuk perempuan dan anak korban kekerasan yakni P2TP2A. dalam menjalankan fungsinya, P2TP2A melibatkan berbagai pihak terkait seperti kepolisian, rumah sakit, organisasi swadaya masyarakat, perguruan tinggi dan organisasi kemasyarakatan lainnya.

Selain itu, secara sendiri-sendiri muapun berkoordinasi, lembaga-lembaga yang terkait dengan layanan untuk perempuan dan anak korban kekerasan memberikan layanan bagi perempuan dan anak korban kekerasan seperti rumah sakit, puskesmas, kepolisian, dan lembaga-lembaga sosial yang secara khusus memberikan layanan pendampingan langsung. Lembaga yang terakhir ini seringkali disebut dengan women's crisis center atau pusat krisis untuk perempuan.

Keberadaan pusat krisis untuk perempuan dan anak yang diinisiasi oleh masyarakat sipil di Indonesia jauh mendahului inisiatif pemerintah dengan P2TP2Anya. Pusat krisis ini pertama kali muncul pada tahun 1993 setelah munculnya deklarasi PBB tentang Penghapusan Kekerasan terhadap Perempuan pada tahun yang sama. Munculnya pusat krisis untuk perempuan dan anak di Indonesia ini tidak dapat dilepaskan dari konteks global yakni menguatnya gerakan advokasi untuk kasus kekerasan terhadap perempuan dan anak. 
Saat ini pusat krisis untuk perempuan korban kekerasan tersebar di berbagai kota di Indonesia. Meskipun demikian, keberadaan pusat krisis ini masih terbatas di beberapa kota saja dan belum merata ke seluruh Indonesia. Menurut data Komnas Perempuan, setidaknya ada 215 pusat krisis untuk perempuan korban kekerasan, meskipun jumlah ini belum dapat dipastikan (Murtakhamah, 2015). Pusat krisis ini tidak saja memberikan layanan di center atau di pusat layanan akan tetapi beberapa di antaranya mengembangkan pusat krisis berbasis komunitas sebagai strategi untuk mendekatkan layanan bagai perempuan korban kekerasan. Selain itu, pusat krisis berbasis komunitas juga dimaksudkan untuk memandirikan komunitas dalam upaya pencegahan dan penanganan korban serta mencegah tercerabutnya korban dari komunitasnya.

Salah satu unsur penting dari pusat krisis untuk perempuan dan anak ini adalah ketersediaan layanan shelter atau rumah aman atau tempat penampungan sementara bagi perempuan dan anak korban kekerasan yang terancam keselamatan jiwanya atau membutuhkan penanganan intensif karena akibat kekerasan yang mereka alami. Rumah aman atau shelter sebagai kebutuhan penting perempuan dan anak korban kekerasan juga sudah menjadi bagian atau unsur penting P2TP2A sebagai pusat krisis yang dikembangkan oleh pemerintah.

Meskipun nampak kemajuan yang penting dalam penyelenggaraan pemulihan untuk perempuan dan anak korban kekerasan, namun persoalan persoalan yang menghalangi pemulihan masih terjadi di sana-sini. Hal ini sebagaimana terekam dalam kajian yang dilakukan oleh Rifka Annisa tentang pelaksanaan UUPKDRT di Indonesia pada tahun 2008 serta kajian pemantauan penanganan kasus kekerasan seksual yang dilakukan oleh Forum Pengada Layanan bersama Komnas Perempuan pada tahun 2015. Temuan ini cukup relevan dan penting untuk diambil pelajaran untuk saat ini di antaranya adalah pertama, pemahaman aparat hukum tentang substansi undang-undang terkait dengan kekerasan 
terhadap perempuan dan anak. Di antaranya pemahaman aparat hukum terkait dengan konsep-konsep dasar misalnya definisi tentang kekerasan. Antara satu hakim dengan hakim yang lain masih terdapat perbedaan dalam mendefinisikan kekerasan. Misalnya kekerasan fisik hakim memiliki perbedaan pendapat mana yang dapat dikelompokkan sebagai kekerasan fisik ringan, sedang, atau berat (Hasyim, N. Kurniawan, AP., 2009 : 15-16).

Selain persoalan substansi hukum, persoalan pemulihan anak korban kekerasan menghadapi tendensi judicial stereotyping di kalanganan aparat penegak hukum yang ditunjukkan dengan sikap tidak dipercaya, menyalahkan korban, atau tidak diterima laporan korban karena dianggap tidak cukup bukti atau kasus dihentikan dengan mengeluarkan SP3 karena alasan tidak adanya cukup bukti.

Kedua, Layanan pemulihan sebagai hak kadangkala harus dikalahkan dengan persoalan administrasi misalnya perempuan atau anak korban kekerasan terhalang untuk mendapatkan layanan misalnya tidak diterima laporannya karena ketiadaan surat identitas, akta nikah, atau surat keterangan miskin, kepesertaan dalam jaminan sosial dan kesehatan.

Ketiga, perempuan atau korban kekerasan harus mengeluarkan biaya untuk mendapatkan layanan kesehatan seperti pemeriksaan kesehatan atau untuk mendapatkan visum. Bahkan korban juga masih harus membayar pemeriksaan psikologis atau pendampingan hukum. Belum lagi korban harus mengeluarkan uang yang tidak sedikit dalam rangka untuk memperoleh keadilan seperti untuk transportasi, makanan selama proses pananganan, bahkan harus kehilangan pendapatan karena harus meninggalkan pekerjaan.

Keempat, tendensi untuk mendamaikan atau penyelesaian di luar proses hukum juga masih sangat tinggi di kalangan masyarakat untuk kasus kekerasan terhadap anak terutama kasus kekerasan seksual bahkan masih ada praktek menikahkan korban dengan pelaku kekerasan seksual. 
Terkait dengan penyelesaian di luar persidangan ini cenderung meningkat dengan dikeluarkan Undang-Undang Nomor 11 tahun 2012 tentang Sistem Peradilan Pidana Anak yang diantaranya mengatur tentang diversi atau pengalihan penyelesaian perkara anak dari proses peradilan pidana ke proses di luar peradilan pudana. Dalam beberapa kasus upaya perdamaian dilakukan dengan dalih diversi namun prasyarat diversi diabaikan. Dalam beberapa pertemuan workshop dan pelatihan Forum Pengada Layanan ditemukan bahwa mekanisme diversi berpotensi digunakan aparat penegak hukum untuk mendapatkan keuntungan finansial (korupsi) dengan modus mengupayakan damai namun dengan syarat imbalan material dari keluarga pelaku.

Kelima, terbatasnya anggaran untuk penanganan kasus kekerasan terhadap perempuan. Penanganan anak dan perempuan korban kekerasan membutuhkan anggaran yang besar karena menyangkut pelayanan langsung tidak hanya persoalan tenaga pendamping seperti konselor, psikolog, petugas kesehatan dan sebagainya akan tetapi juga operasional seperti penyelenggaraan rumah aman yang meliputi bangunan dan biaya operasional termasuk biaya-biaya rujukan dan intervensi medis. Besarnya biaya ini tidak diimbangi dengan kebijakan anggaran yang maksimal. Kajian tentang anggaran untuk penanganan kasus kekerasan terhadap perempuan yang dilakukan oleh Legal Resource Center KJHAM Semarang menunjukkan bahwa anggaran untuk penanganan kasus kekerasan terhadap perempuan sangat kecil jika dibandingkan dengan anggaran lainnya misalnya anggaran untuk pengadaan pakaian dinas pegawai. Kajian tentang Tren Anggaran Belanja Penanganan Kasus Kekerasan terhadap Perempuan ini juga menemukan bahwa anggaran untuk penanganan kasus kekerasan terhadap perempuan di Propinsi Jawa Tengah hanya 0,01 persen dibandingkan dengan anggaran kunjungan angora DPRD (Hafidhoh dan Yuliana, 2015: 32) . Di Kabupaten Wonosobo anggaran untuk penanganan kasus kekerasan terhadap perempuan pada tahun 2014 hanya 5,7 persen 
dari total belanja untuk tambahan penghasilan bagi PNS. (Hafidhoh dan Yuliana, 2015: 87).

Berkaitan dengan problem tersebut, rekomendasi yang ditawarkan dalam artikel ini antara lain; pertama, penguatan kapasitas aparat penegak hukum, petugas kesehatan dan juga pendamping di pusat-pusat layanan untuk anak korban kekerasan. Penguatan kapasitas ini meliputi pemahaman akan persoalan kekerasan terhadap anak dan perempuan, perspektif hak anak, serta kecakapan dalam melakukan pendampingan terhadap anak sebagai tambahan dari keahlian yang sudah dimiliki. Lebih lanjut, penguatan kapasitas sumber daya manusia ini harus menjadi bagian dari sistem pelayanan dari berbagai lembaga terkait sehingga ketika terjadi mutasi pegawai tidak mempengaruhi pelayanan.

Kedua, mempermudah layanan dengan mengedepankan kebutuhan anak korban kekerasan dan menempatkannya sebagai hak yang tidak dapat direduksi oleh masalah administrasi. Menjadi penting bagi aparat hukum, petugas kesehatan, pendamping untuk memiliki prinsip penanganan segera dan mengedepankan kepetingan yang paling baik bagi anak.

Ketiga, kebijakan anggaran yang memberikan porsi yang lebih besar pada pemulihan dari pos anggaran lainya dalam mekanisme penyelenggaraan pemulihan. Anggaran harus diarahkan pada kepentingan pemulihan dan anggaran untuk pemulihan anak korban kekerasan harus mendapatkan porsi yang lebih besar dari pada pospos lainnya seperti gaji, kunjungan dan pelatihan. Dengan anggaran ini diharapkan korban tidak akan mengeluarkan biaya atas hal yang seharusnya menjadi kewajiban negara seperti biaya penanganan medis, penanganan psikologis, visum dan biaya-biaya lainnya seperti pemulangan dan reintegrasi.

Keempat, meningkatkan kerjasama antar sektor dalam penyelenggaraan pemulihan anak korban kekerasan. Pemulihan adalah meliputi fungsi lembaga layanan yang beragam dan untuk dapat menyelenggarakan pemulihan anak korban kekerasan yang 
paripurna diperlukan kerjasama yang efektif dari berbagai sektor.

Kelima, Penyelesaian hukum terhadap persoalan kekerasan terhadap anak, lebih-lebih kekerasan seksual, adalah pilihan terbaik dan aparat hukum harus mendorong upaya penyelesaian secara hukum kecuali dibenarkan upaya lain menurut undang-undang seperti mekanisme diversi untuk kekerasan terhadap anak yang pelakunya juga berstatus anak. Dalam hal ditempuh langkah diversi, aparat penegak hukum dan pendamping harus memastikan seluruh prasyarat dan prosedur terpenuhi. Upaya-upaya mendamaikan atau melakukan penyelesaian di luar hukum seperti menikahkan anak korban kekerasan seksual dengan pelaku harus dihindari untuk kepentingan yang paling baik bagi anak korban kekerasan.

\section{Simpulan}

Penyelenggaraan pemulihan untuk anak korban kekerasan adalah hak anak. Sebagai hak, maka negara memiliki kewajiban untuk memenuhinya dengan segala sumberdaya yang dimiliki. Pada dasarnya pemerintah Indonesia telah memiliki kebijakan yang memadai terkait dengan penyelenggaraan pemulihan anak korban kekerasan namun dalam pelaksanaannya mengalami sejumlah hambatan. Hambatan yang ditemukan berkaitan dengan penguatan kapasitas penegak hukum, kebijakan anggaran, sinergi antar sektor, birokrasi yang panjang dan berbelit, dan penguatan budaya dukungan bagi anak korban kekerasan. Dengan demikian upaya untuk menyelesaikan problem tersebut menjadi prasyarat bagi terwujudnya pemulihan anak korban kekerasan yang berkelanjutan. 


\section{DAFTAR PUSTAKA}

BKKBN, BPS, Kementerian Kesehatan, 2013. Survei Demografi dan Kesehatan Indonesia 2012. Jakarta: BKKBN, BPS, dan Kementerian Kesehatan.

Hafidhoh, N., Yuliana, I., 2015. Kewajiban Minus Konsekuensi Anggaran. Semarang: LRC KJHAM Semarang .

Hasyim, N. Kurniawan, AP., 2009. Pemantauan Implementasi Undang-Undang Penghapusan Kekerasan dalam Rumah Tangga di Enam Provinsi di Indonesia. Pertama ed. Yogyakarta: Rifka Annisa bekerjasama dengan Foundation Open Society Institute.

Hasyim, N., 2015. www.komnasperempuan.go.id. [Online] Tersedia di: http://www.komnasperempuan.go.id/ konferensi-nasional-pemulihan-membincangkonsep-pemulihan-dalam-makna-luas-hari-kedua/ [Diakses pada tanggl 8 Oktober 2016].

Kementerian Kesehatan RI, 2014. Riset Kesehatan Dasar 2013. Jakarta: Kementerian Kesehatan RI.

Kementerian Pemberdayaan Perempuan dan Perlindungan Anak Bekerjasama dengan Biro Pusat Statistik, 2015. Profil Anak Indonesia 2015. Jakarta: Kementerian Pemberdayaan Perempuan dan Perlindungan Anak bekerjasama dengan Biro Pusat Statistik.

Kementerian Perbedayaan Perempuan dan Perlindungan Anak, 2016. www.kemenpppa.go.id. [Online]. Tersedia di http://www. kemenpppa.go.id/index.php/page/read/29/188/press-releasefluktuasi-jumlah-kasus-kekerasan-perlu-diwaspadai/ [Diakses pada tanggal 8 Oktober 2016]

Komnas Perempuan, 2016. Lembar Fakta Catatan Tahunan (Catahu) 2016: Kekerasan terhadap Perempuan Meluas: Mendesak Negara Hadir Hentikan Kekerasan terhadap Perempuan, 
Jakarta: Komnas Perempuan.

Komnas Perempuan, n.d. Divisi Pemulihan. [Online] Tersedia di: http://www.komnasperempuan.go.id/ struktur-organisasi-2/program/divisi/pemulihan/ [Diakses pada tanggal 8 Oktober 2016].

Murtakhamah, T., 2015. www.kompasiana.com. [Online]. Tersedia di: http://www.kompasiana.com/titin_murtakhamah/ mengenal-lebih-dekat-pusat-krisis-perempuan-di-indonesia_5 52a2df1f17e615668d623dd. [Diakses pada tanggal 8 Oktober 2016]

Setyawan, D., 2015. www.kpai.go.id. [Online] Tersedia di: http://www.kpai.go.id/berita/kpai-pelakukekerasan-terhadap-anak-tiap-tahun-meningkat/ [Diakses pada tanggal 8 Oktober 2016]. 